
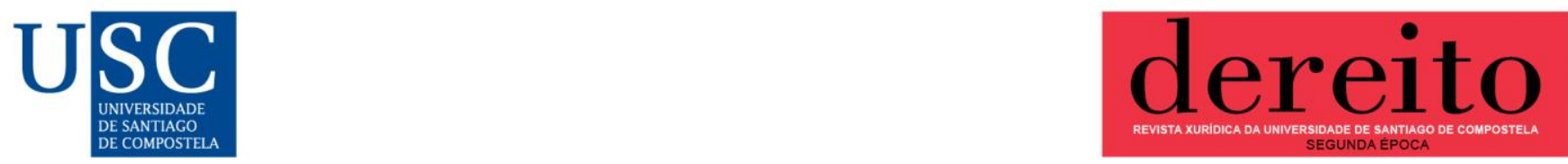

Dereito: revista xurídica da Universidade de Santiago de Compostela, 30 (1), 2021. ISSN: 2174-0690

https://doi.org/10.15304/dereito.30.1.7352

Recensiones

\title{
BACIGALUPO SAGGESE, Mariano et al., Jurisdicción contencioso-administrativa, Tirant lo Blanch, Valencia, 2019
}

\author{
Cristina Alonso Salgado ${ }^{1}$ \\ Profesora Axudante Doutora de Dereito Procesual, Universidade de Santiago de Compostela, España \\ cristina.alonso@usc.es
}

Por herética que poida resultar a afirmación, alomenos a xuízo de quen estas liñas escribe, a orde xurisdicional contencioso-administrativa representa hogano, un dos ámbitos tecnicamente máis complexos do panorama xurídico español. 0 seu obxecto, leitmotiv e, por que non dicilo, a súa propia evolución histórica acompañan, sen dúbida, a referida cualificación.

Inzado de especificidades, singularidades e rarezas, a súa radiografía revela un océano de dificultades endóxenas, xunto con outras tantas de orixe esóxena. En efecto, ás complexidades propias, cómpre engadir outras alleas de indubidábel relevancia, por exemplo, a coñecida orfandade de perspectiva procesual de non poucas análises da Lei 29/1998, de 13 de xullo, reguladora da "Xurisdición" Contencioso-administrativa.

Malia facer parte do terreo do evidente, cómpre verbalizalo en atención a unha contextualización absolutamente imprescindíbel: fai anos que a doutrina procesual ten desatendido o estudo do proceso contencioso-administrativo. Sexa polo motivo que for afortunadamente non nos podemos deter nisto- a literatura especializada teima en devolver unha realidade que, non por obvia, deixa de causar estrañeza e abraio a partes iguais. A prevención resulta procedente, xustamente, para situar nas coordenadas correctas aos non iniciados con vocación de tropezar co proceso contencioso-administrativo.

Sentadas as cautelas para nos mergullar con seguridade na obra que agora interesa, corresponde comezar apuntando que "Jurisdicción contencioso-administrativa" constitúe, por riba de calquera outra consideración -e malia o desafortunado do título-, unha moi boa nova. E isto porque, para alén das apreciacións que a continuación se debullan, constitúe un fantástico exemplo sobre como escolmar os debates imprescindíbeis dun determinado ámbito a través do fío condutor dunha obra colectiva.

Dende os preitos-testemuña, a cuestión de ilegalidade ou os case inéditos procedementos para a garantía da unidade de mercado e para a declaración xudicial de extinción de partidos políticos, até a execución forzosa, a inexecución de sentenzas, ou o novo sistema casacional, a publicación analiza minuciosamente a orde contencioso-administrativa para facer notar todos os aspectos susceptíbeis de controversia.

Non anticipamos nada que non esteamos en disposición de acreditar. Véxanse pois, algunhas pinceladas do acabado de indicar. 
Así, verbo do "Ámbito y extensión de la jurisdicción contencioso-administrativa", subliña MONTERO PASCUAL que a Lei 29/1998 non é senón o resultado da vis expansiva da fiscalización xurisdicional do Poder Executivo tanto no seu prisma gobernativo, coma no administrativo. Resulta ben doado identificar os elementos nos que se amosa esa vis da que vimos de dar conta: en primeiro lugar, ao abeiro do modelo de control xudicial da actividade da Administración derivado da Constitución de 1978, non cabe dúbida de que a contenciosoadministrativa é unha orde xurisdicional en toda a extensión do concepto. En segundo lugar, en boa lóxica, non se trata dunha segunda instancia de revisión do acto administrativo, senón dunha orde xurisdicional plena. Asemade, en terceiro lugar, máis alá dos referidos actos, o seu ámbito abrangue -malia que limitadamente-, os actos de goberno, xunto cos actos materialmente administrativos doutros entes públicos. Por último, a sinalada onda extensiva ten incorporado nos últimos tempos, competencias de autorización previa de actos administrativos particularmente gravosos para os dereitos fundamentais.

Co fío no que se acaba de referir, en relación ao obxecto do recurso contenciosoadministrativo, BACIGALUPO SAGGESE volve insistir nunha idea xa salientada: a relativa á ampliación do abano de actuacións e omisións que poden erixirse na cerna do sinalado recurso e, xa que logo, a correlativa diversificación das ferramentas procesuais artelladas co gallo de ofrecer unha tutela xudicial realmente efectiva.

Baixo o título "La sentencia y otros modos de terminación del proceso" abórdanse no capítulo sétimo -entre outras cuestións-, algunhas das especialidades das sentenzas na orde contencioso-administrativa, a saber: o pronunciamento na parte dispositiva verbo da inadmisibilidade, a desestimación ou a estimación do recurso; a súa eficacia subxectiva supeditada ao contido do fallo; a singularidade referente aos umbrais das sentenzas anulatorias de disposicións xerais; etc.

Sen ánimo de anticipar máis que algúns dos principais treitos da arquitectura da obra, finalizamos a nosa modesta monitorización co capítulo relativo a "Los recursos en el proceso contencioso-administrativo". Non podería ser doutro xeito: a Lei Orgánica 7/2015, de 21 de xullo, pola que se modificou a Lei Orgánica do Poder Xudicial reformou substancialmente o recurso de casación co gallo de que cumprise estritamente a súa función nomofiláctica, deseñando en tal sentido, un mecanismo de admisión dos recursos fundamentado na descrición dos supostos susceptíbeis de acceder ao Tribunal Supremo por concorrer interese casacional.

Ben sabemos que o sinalado ata o de agora non lle fai en absoluto xustiza á obra. Son moitas as cuestións que quedan no tinteiro pendentes de seren escritas. No entanto, o entremés serve para, alomenos, permitir que o lector interesado faga súa unha composición de lugar sobre os principais extremos da publicación.

Para poñer o ramo e polo que a nós respecta: nin que dicir ten que, sen dúbida, a obra merece ser visitada. Certo é que as pinceladas que se veñen de ofrecer non presentan unha realidade adozada: a temática é abrupta, con recantos, bordos e saíntes dunha complexidade técnica máis que notábel. Porén, a fondura analítica é compensada cun manexo lixeiro da pluma; e, a adustez do percorrido intelectual, co pulo xeneroso e didáctico dos autores e autoras.

En definitiva, a súa consulta resulta de interese porque, para alén doutras consideracións, proporciona, con indubidábel acerto, un exame exhaustivo e crítico das principais controversias da orde contencioso-administrativa presentes actualmente no debate especializado. 
${ }^{1}$ FEDER/Ministerio de Ciencia, Innovación y Universidades - Agencia Estatal de Investigación/_Proyecto "Veinte años de la LJCA: una revisión crítica desde la perspectiva procesal" (DER2017-88678-P).

"Axuda da Xunta de Galicia para a consolidación e estruturación de unidades de investigación competitivas de Galicia (grupos de potencial crecemento)" para o período 2019/2021 (exp. ED431B 2019/14). 